\title{
Assessment of Ongoing Training in Restorative Practices
}

\author{
Evaluación de la formación permanente en prácticas restaurativas \\ Avaliação do treinamento permanente em práticas de restauração
}

María Isabel Pomar

Universidad de las Islas Baleares Mallorca, España

maribel.pomar@uib.es

https://orcid.org/0000-0001-9005-670X

Carme Pinya

Universidad de las Islas Baleares

Mallorca, España

carme.pinya@uib.es

http://orcid.org/0000-0002-5165-304X

Recibido • Received • Recebido: 15 / 09 / 2018

Corregido • Revised • Revisado: 30 / 01 / 2020

Aceptado • Accepted • Aprovado: 01 / 04 / 2020

\begin{abstract}
This research aims to show the impact of training actions on restorative practices in a group of teachers who were not well versed in this issue. The purpose was to find and compare the views the training attendees had beforehand and upon completion about conflicts and how to tackle them. At the same time, the intention was to analyze the role training strategies played in changing attitudes.
\end{abstract}

Keywords: Ongoing training; restorative practice; safe and caring schools; teacher training.

Resumen: La finalidad de esta investigación es mostrar la incidencia que tienen las acciones formativas sobre prácticas restaurativas en un grupo de docentes que desconoce la temática. Se persigue recoger y comparar las concepciones sobre los conflictos y su abordaje de los sujetos asistentes a la formación antes de que esta tenga lugar y una vez finalizada. Al mismo tiempo, se pretende analizar el papel que juegan las estrategias formativas en el cambio de concepciones.

Keywords: Formación permanente; prácticas restaurativas; escuelas saludables; formación del profesorado.

Resumo: O objetivo desta pesquisa é mostrar o impacto de ações formativas sobre práticas restaurativas num grupo de professores que desconhecem o assunto. O objetivo é coletar e comparar as concepções sobre conflitos e sua abordagem dos sujeitos participantes do treinamento antes que ela ocorra e uma vez terminada. Ao mesmo tempo, pretende-se analisar o papel desempenhado pelas estratégias de formação na mudança de concepções.

Palavras chaves: Formação permanente; práticas restaurativas; escolas saudáveis; formação de professores. 
http://doi.org/10.15359/ree.24-2.14

ROR: https://ror.org/01t466c14 Universidad Nacional, Costa Rica

http://www.una.ac.cr/educare

educare@una.cr

\section{Introduction}

Restorative practices originate in what is known as restorative justice, a way of seeing criminal justice that emphasises how the offence harms relationships between the people living in a community. As opposed to retributive justice, which focuses on finding out who is guilty and imposing a sanction on them, restorative justice seeks to repair the harm and to restore relationships, since these are based on respect for the dignity of all the people affected by the offence, and because the treatment of the participants' needs are prioritised (Braithwaite, 2002, 2006).

That is, the process of restorative justice encourages the offender to take responsibility for their actions and for the harm caused, to understand the causes and effects of their behaviour on others and to offer solutions that will repair the harm in order for them to be accepted back into the community; from the recognition that it is the deeds that are judged, not the person (Braithwaite, 2002). Meanwhile, the process offers the victim the possibility of asking questions and obtaining answers, so as to be able to understand, to explain the impact of the offence, and to explain their point of view as to how to repair the harm and to reintegrate the offender into the community (Zehr, 2005).

According to McCold \& Wachtel (2003), this new approach of involving all the people affected by an offence in the correction process and obtaining the personal control associated has a great potential to optimise social cohesion, on the basis of three central ideas: repair (the harm must be repaired), encounter (communication and decision-making by all the persons affected), and transformation (profound changes in the participants, in their relationships, and within the community).

Beyond the judicial field, restorative practices constitute a range of tools that make it possible to prevent, detect, tackle and resolve situations of conflict (family, educational, social, labour, and community) in order to improve coexistence and to reinforce the affective ties between the people affected by these situations. It could be said that social and emotional competencies are at the core of restorative processes. In the words of Costello et ál. (2009), they are a proposal by and for the community that provides tools so that it can take care of itself.

Restorative practices are, therefore, based on a community perspective of coexistence in which the relationships between people constitute the backbone. Relationships in which cooperation, knowledge of others, respect, and concern for their wellbeing are fundamental elements, as well as the awareness of how our behaviour affects the emotional wellbeing or distress of the people we live alongside.

If we focus on the field of education, restorative practices are a proposal with which to strengthen relationships between all the members of the educational community (Hopkins 2004, 2011); while, as pointed out by different authors (Britto, 2006; McCluskey et ál., 2008; Reimer, 2011), they represent a way of managing conflicts in education centres as opposed to the predominant retributive model (for such an offence, such a sanction), providing a new perspective in which

2

María Isabel Pomar y Carme Pinya

Los artículos de la Revista Electrónica Educare del Centro de Investigación y Docencia en Educación de la Universidad Nacional, Costa Rica, se comparten bajo términos de la Licencia Creative Commons: Reconocimiento, No Comercial, Sin Obra Derivada 3.0 Costa Rica. Las autorizaciones adicionales a las aquí delimitadas se pueden obtener en el correo: educare@una.cr 
pupils learn from the situations of conflict and from problems by taking responsibility and repairing the harm caused. It is not, in any way, a soft proposal or a generator of impunity.

Restorative practices generate community by providing effective, direct ways of teaching pupils -like all adults (Morrison, 2006; Morrison et ál., 2005; Vaandering, 2013; Vaandering, 2014)that they are part of it, that their actions affect others and that they share the responsibility of making their community a place where they would like to live. Thus, restorative practices are directly related to the aim of contributing to the construction of a more democratic society. This ambition, present in many declarations of intent, calls for educational centres to provide pupils with experiences of democratic coexistence. Debate, joint reflection, negotiation and decision-making are proposals that contribute to the real learning of values such as tolerance, pluralism, and participation. This perspective is built day by day, by fostering participation structures so that people have the chance to interact, establish bonds, engage in dialogue, make and share proposals, agree and commit, reflect on actions and ideas; in short, to share their experiences, feelings, needs, and expectations. Educational centres constitute privileged spaces for the application of these practices, both those that are aimed at dealing with conflicts in an alternative way to punitive discipline (Mirsky, 2011), and those that are focused on constructing, maintaining and renewing relationships between all the members of the educational community (Reimer, 2011; Vaandering, 2013, 2014).

From the approach presented, it is necessary to train teachers to deal with this community perspective, both in the relationships they have with their pupils and the ones they have with the rest of the adults that make up their educational community.

Ongoing training, nowadays, has established itself as indispensable for professional development in any workplace; and, as such, for primary and secondary school teachers. The educational community is increasingly aware of the need for ongoing training, in order to improve and innovate and, in short, to provide an adequate educational response to the changing demands of current society, enabling the creation of spaces for training, reflection, innovation, shared learning...

Ongoing teacher training and, consequently, the process of professional development, ought to be decisive factors in improving the quality of education; when we speak of the need to innovate and improve teaching practices, we must consider, in parallel, training that will support this process.

In the case of ongoing training, the protagonists are adults who, in most cases, are working, have experience as a training recipient, and have their own needs/motivations/interests and characteristics as regards the mechanisms of adult learning.

As Feuillette-Cunningham (1995) describes for adults, in relation to training, the usefulness and functionality thereof, personal experience, the professional project, specific applications of the training, and the possibiliities of engaging in it take on relevance. The background with 
http://doi.org/10.15359/ree.24-2.14

ROR: https://ror.org/01t466c14 Universidad Nacional, Costa Rica

http://www.una.ac.cr/educare

educare@una.cr

which an adult comes to the training and how they engage with the new reality presented is crucial to real learning.

As far as the motivations and interests of this group are concerned, it is worth noting the following, as Johnstone \& Rivera (1965) point out: wanting to be better informed, preparing themselves to perform new funcions, improving their skills, increasing their knowledge, relating to new people, escaping from routine, obtaining a diploma, and even filling in free time. Although the motivational starting point is essential in the teaching-learning process, we have strategies to promote motivation toward learning: emphasise the value and importance of the training action, taking tests as a way of verifying the progress made during the training, presenting issues in such a way that they arouse interest, using collaborative strategies, generating curiosity, linking the content to the most personal part, presenting paradoxes for discussion, helping trainees to pose their own challenges, offering constant feedback, teaching by example, stimulating the metacognitive awareness of learning processes (Entwistle 1998); as we shall see, the results of some of these strategies are incorporated in the training experience presented in this article.

Attitudes are another of the pillars in ongoing training; they are learnt, change and are reinforced; according to Jurado (1996, p. 458): "attitude change is made easier when there is a chance to act upon new attitudes". Woolfolk \& MacCuna (1980) speak about the strategies that enable attitude change based on training: establish chances of experiencing continued success in relation to the topic worked on; act upon a personal choice and in agreement with it, and have backing in order to act in accordance with the chosen option.

This study has at its core the teacher training imparted by the Association for Justice and Restorative Practice of the Balearic Islands (Associació de Justícia i Pràctica Restaurativa (2016). This non-profit association constituted in 2013 is aimed, amongst others, at spreading the philosophy and practice of restorative justice, as well as carrying out training activities in order to raise awareness of restorative practices and to pave the way for their implementation in different community settings.

Following the proposal developed by the International Institute for Restorative Practices (IIRP) (2019), the training addresses the whole repertory of restorative practices: from the most informal ones (active listening, expressions of affect) to the most structured ones (formal meetings) which require the intervention of a trained facilitator (Costello et ál., 2010). Likewise, the basic principles of restorative practices and their origins are explained.

\section{Method}

The purpose of this research is to show the impact a training programme has on the views of teachers regarding conflict and how to tackle it. The aim was to gather and compare the perceptions of attendees before and after the training received on restorative practices. At the same time, the intention was to analyse the role played by training strategies in attitude change.

4

María Isabel Pomar y Carme Pinya

Los artículos de la Revista Electrónica Educare del Centro de Investigación y Docencia en Educación de la Universidad Nacional, Costa Rica, se comparten bajo términos de la Licencia Creative Commons: Reconocimiento, № Comercial, Sin Obra Derivada 3.0 Costa Rica. Las autorizaciones adicionales a las aquí delimitadas se pueden obtener en el correo: educare@una.cr 
The research methodology used in the study was a mixed methodology, which included a pretest-postest pre-experimental design and a content analysis of the discussion groups conducted with the course trainers. This methodology enabled us to describe the training programme in detail and to verify whether it worked in the way we expected; although we did not have a control group, we accommodated internal comparisons, as has been done in similar studies: Abraham et ál. (2008), Hall et ál. (2004), and Degani et ál. (2009). In addition, it was our intention to explain the changes that took place after the training action and to identify what may be related to these changes.

The discussion group enabled us to carry out a situation of group interaction where a number of people engage in a dialogue concerning the processes and situations that are the object of study. Besides, from this instrument, in order to make the issue studied intelligible, we introduced relevant research questions that had not been detected or highlighted in the formulation of the objectives or in the questionnaire instrument.

In accordance with this purpose, the study posed the following hypotheses:

1. The assessments that trainees make of conflict, its treatment, and the role of the community vary depending on the educational stage in which they are teaching.

2. There are statistically significant differences as regards the view of conflicts, resolution, and the role of the community given before and after the training period.

3. There is a positive correlation between the diverse categories making up the dimensions of the study.

4. Training strategies are key to facilitating attitude change in teachers.

\section{Sample}

The universe of the study is made of the 60 trainees enrolled in ongoing teacher training on restorative practices. Based on intentional sampling, out of the total population of the 60 subjects enrolled in the training, a sample was collected that, in the pre-test implementation of the questionnaire, was 52 and, in its post-test implementation, also 52 subjects. These figures finally made up a sample with a margin of sampling error of 4.5, for a confidence interval estimate of $95 \%$.

The age of the trainees participating in the study oscillated between 24 and 54 years, with a mean age of 40 years.

The sample was made up of $72.7 \%$ women, and only $15.2 \%$ men, a percentage that corresponds to the distribution of the teaching population and its feminisation. 
http://doi.org/10.15359/ree.24-2.14

ROR: https://ror.org/01t466c14 Universidad Nacional, Costa Rica

http://www.una.ac.cr/educare

educare@una.cr

The participants in the training were mainly Primary Education teachers (42.4\%), although there was some representation from other stages of education: Early Childhood (12.1\%); Secondary Education (14.1\%); Social Services (1\%) and Special Needs classrooms (4\%); while $26 \%$ of the sample did not specify the educational stage in which they worked.

Subsequent to the application of the questionnaires, a discussion group with trainers from the Association for Justice and Restorative Practice was conducted. The group was made up of 7 people ( 6 trainers and the moderator, one of the authors of this article). Of the 6 trainers, 3 (trainer 1, trainer 2 and trainer 3 ) had been carrying out introductory courses to restorative practices since 2013, and the other 3 (trainer 4, trainer 5, trainer 6) began doing this less than a year ago although they had been involved in support activities to this training for longer.

\section{Instrument}

To obtain the data, a questionnaire entitled Questionnaire on the beliefs and opinions on restorative practices (Cuestionario sobre las creencias yopiniones sobrelas prácticas restorativas) was designed, which was made up of 27 items, divided into 3 dimensions: conflict, conflict resolution process, and community. The instrument collected information concerning the identification details of the sample (age, gender and stage of education in which they taught). It was a 4-point Likert scale in which a score of 1 indicated never or hardly ever, and a score of 4 indicated always.

The questionnaire was subjected to a contrasting process by judges, based on a Delphi Panel composed of 8 university lecturers knowledgeable in the subject; 100\% response was obtained and $90 \%$ agreement. A pilot test was also conducted with a group of 10 trainees, after which total agreement was achieved between the vision of the interviewer and that of the participating trainees.

Members of the research team administered the questionnaire at two different times (before and after the training period). Participants answered individually, voluntarily, and with no time limit; their privacy was respected while their answers were processed.

It is also worth mentioning the fact that after this double application of the questionnaire, the internal consistency of each of the three categories established was assessed. A repertoire of scales with a reliability oscillating between 0.40 and 0.7 was obtained, wherefore the internal consistency was considered adequate, as reflected in the Table 1:

Table 1: Reliability coefficients by scales

\begin{tabular}{lc}
\hline Scales & Cronbach's alpha \\
\hline Conflict & .402 \\
Resolution & .465 \\
Community & .775 \\
\hline
\end{tabular}

Note: Own elaboration. 
The internal consistency, or homogeneity, between the items in the questionnaire was assessed by applying Cronbach's alpha coefficient, the values of which ranged between 0 and 1 , while the values were $0.40,0.47$ and 0.77 respectively for each of the categories making up the questionnaire. Two of the values were less than 0.70 , generally considered acceptable. Nevertheless, we find authors such as Cortina (1993) who show that the alpha value depends on multiple factors; wherefore, theoretically low values cannot be ruled out, or theoretically high values be blindly accepted. Hence, measurements with a relatively low reliability may turn out to be useful (Schmitt, 1996), whereas some very high coefficients may indicate excessive redundancy in the items; therefore, there are authors who recommend a maximum value of 0.90 (Streiner, 2003).

The discussion group was designed and carried out in order to study the role of training strategies in the attitude change of teachers. The group was initially posed the question of the training strategies used in the introductory courses to restorative practices, although contributions were made regarding the content thereof.

\section{Procedure}

To achieve the proposed aims, a mixed methodology was chosen, based on the questionnaire technique and on the discussion group.

It was planned to administer the questionnaire at two different times: before (pre-test) and after (post-test) the training period, which would enable the changes taking place during this time to be evidenced.

Then, the discussion group was conducted with the trainers; this took place in a comfortable space and in a climate of trust. It lasted 2 hours and was audio recorded for its subsequent transcription and analysis.

As far as the intervention was concerned, it consisted of the implementation of a training programme. The training lasted at least 9 hours and was eminently practical, such that in the sessions (usually 3 ) the participants carried out a whole series of activities that connected with their reality as teachers and gave them the need to create healthier and safer schools (Mirsky, 2011).

Below, an abbreviated script of the training is presented, containing the contents and the activities proposed to the attendees (Table 2). 
http://doi.org/10.15359/ree.24-2.14

ROR: https://ror.org/01t466c14 Universidad Nacional, Costa Rica

http://www.una.ac.cr/educare

educare@una.cr

Table 2: Structure of the training in restorative practices (RP)

\begin{tabular}{|c|c|}
\hline Contents & Activities \\
\hline \multicolumn{2}{|l|}{ SESSION 1} \\
\hline \multirow{4}{*}{$\begin{array}{l}\text { What RP are: origin and brief } \\
\text { explanation. } \\
\text { - Relationship with educational } \\
\text { styles. } \\
\text { - Attending to needs }\end{array}$} & - Initial circle: presentation of participants. \\
\hline & - Individually (anonymously) write down a conflict, share it in pairs and comment \\
\hline & what they would have needed in that situation to resolve it satisfactorily. \\
\hline & $\begin{array}{l}\text { - Circle: each attendee reads one of the conflicts and says what they would } \\
\text { have needed. }\end{array}$ \\
\hline \multirow{9}{*}{$\begin{array}{l}\text { Community: characteristics } \\
\text { that define it. } \\
\text { - A circle as a tool to create } \\
\text { community and prevent } \\
\text { conflicts. }\end{array}$} & $\begin{array}{l}\text { - In circles of 4-6 people, they appoint a facilitator and answer the following } \\
\text { questions: }\end{array}$ \\
\hline & - To start: one thing you would take to a desert island \\
\hline & -What is done at your workplace to create community? \\
\hline & -What you appreciate most in your colleagues \\
\hline & - One occasion when you have felt very comfortable at work \\
\hline & - To end: one thing you will take away from this circle \\
\hline & - Circle of sharing: what we get from talking in a circle. \\
\hline & $\begin{array}{l}\text { - New circles of 4-6 personas, they appoint a facilitator and a secretary and } \\
\text { answer the following questions: }\end{array}$ \\
\hline & - To start: a pleasant way to spend a Sunday \\
\hline \multirow{6}{*}{ • How they work } & -What could circles contribute to my work? \\
\hline & -When could I use them and what for? \\
\hline & -What issues could be dealt with in a circle? \\
\hline & • How often? \\
\hline & - To end: one thing or idea I have liked in this circle \\
\hline & $\begin{array}{l}\text { - Circle of sharing: each secretary reads one of the contributions of the } \\
\text { groups and the others complete them. Gather the contributions that will } \\
\text { subsequently be handed out to all the training attendees. }\end{array}$ \\
\hline $\begin{array}{l}\text { Possibilities of dialogue } \\
\text { circles: }\end{array}$ & $\begin{array}{l}\text { - Show examples of circles from different educational centres and their } \\
\text { diverse use. }\end{array}$ \\
\hline \multirow{4}{*}{\multicolumn{2}{|c|}{$\begin{array}{l}\text { - getting to know others, } \\
\text { - making yourself known, } \\
\text { - establishing goals, } \\
\text { - assessing, etc. }\end{array}$}} \\
\hline & \\
\hline & \\
\hline & \\
\hline $\begin{array}{l}\text { Repertoire of restorative } \\
\text { practices. }\end{array}$ & - Session closure circle: what you are taking away from today's session. \\
\hline
\end{tabular}

continúa 


\begin{tabular}{|c|c|}
\hline Contents & Activities \\
\hline \multicolumn{2}{|l|}{ SESSION 2} \\
\hline & - Initial circle. \\
\hline Active listening & - Active listening practice so as to experience its effects. \\
\hline \multirow[t]{2}{*}{ Expressions of affect } & $\begin{array}{l}\text { - Three by three, practise expressions of affect based on specific cases that } \\
\text { they remember. }\end{array}$ \\
\hline & $\begin{array}{l}\text { - Large sharing circle: at what time do expressions of affect have special } \\
\text { relevance? What use are they? }\end{array}$ \\
\hline \multirow[t]{2}{*}{ Restorative questions } & - Modelling a situation based on an example. \\
\hline & $\begin{array}{l}\text { - In pairs, ask each other questions, in two situations in which there has } \\
\text { been unwanted or incorrect behaviour. }\end{array}$ \\
\hline Informal meeting & - Session closure circle: one brief sentence to refer to today's session. \\
\hline \multicolumn{2}{|l|}{ SESSION 3} \\
\hline & - Initial circle. \\
\hline The restorative circle & $\begin{array}{l}\text { - Practice based on a problem posed by the trainers. Groups of } 7 \text { are formed } \\
\text { and the roles divided between the participants, including the facilitator of } \\
\text { the circle. The facilitator asks the questions proposed by the trainers. }\end{array}$ \\
\hline \multicolumn{2}{|l|}{ Formal meetings } \\
\hline \multirow[t]{3}{*}{ Social Discipline Window } & - Modelling based on some everyday situations. \\
\hline & $\begin{array}{l}\text { - Form teams of between } 4 \text { and } 6 \text { people and think of answers to problematic } \\
\text { situations from each of the quadrants of the window. }\end{array}$ \\
\hline & $\begin{array}{l}\text { - Sharing circle: what use is the window? What position do I most often find } \\
\text { myself in? (The second question is voluntary). }\end{array}$ \\
\hline \multirow[t]{2}{*}{ Fair process } & $\begin{array}{l}\text { - Based on some of the examples worked on before, highlight the elements } \\
\text { of fair process. }\end{array}$ \\
\hline & $\begin{array}{l}\text { - Sharing circle: what isn't fair process? What happens when the principles of } \\
\text { fair process are not respected? (Voluntary). }\end{array}$ \\
\hline \multirow[t]{2}{*}{$\begin{array}{l}\text { Adaptation of restorative } \\
\text { practices to the workplace }\end{array}$} & $\begin{array}{l}\text { - In groups of } 5 \text { or } 6 \text { participants discuss in a circle format the adaptation of } \\
\text { RP to your work context: What do we need? How can we use RP? }\end{array}$ \\
\hline & $\begin{array}{l}\text { - Session closure circle: image analogy assessment of the training in } \\
\text { restorative practices. }\end{array}$ \\
\hline
\end{tabular}

Note: Own elaboration.

\section{Data analysis}

The analysis was performed using the Statistical Package for the Social Sciences (SPSS 21). In the first phase of the results analysis, a descriptive analysis of the dimensions and items in the questionnaire was carried out. 
http://doi.org/10.15359/ree.24-2.14

ROR: https://ror.org/01t466c14 Universidad Nacional, Costa Rica

http://www.una.ac.cr/educare

educare@una.cr

In order to analyse competencies according to the variables of age, gender and stage of education in which the participants in the study taught, contingency tables were constructed and Pearson's chi-square independence test was applied.

For the analysis and comparison of results between pre- and post-test, Sudent's $t$ test for paired data was carried out, which made it possible to verify whether a significant change was produced in the mean values awarded by the subjects participating in the study.

Meanwhile, the qualitative data analysis package NVIVO (version 10) was used for coding and analysing the content of the discussion group. The following categories, reflected in Table 3, were created inductively to analyse the information collected:

Table 3: Qualitative information categories of analysis

\begin{tabular}{ll}
\hline Category & Subcategories \\
\hline Effective training strategies & 1.1 Start from the experiences of the attendees \\
1.2 ctive, constant participation of the attendees \\
1.3 Modelling through use in training in restorative strategies \\
1.4 Relationship with the professional commitment of the attendees \\
\hline
\end{tabular}

Note: Own elaboration.

\section{Results}

In the first phase of the result analysis, before starting the verification of the hypothesis of the study, inferential statistics were performed on the different items; thereby obtaining data as to the mean and standard deviation of each one, which are reflected in Table 5.

Secondly, the first hypothesis was checked, finding with the contingency tables and Pearson's chi-square test for independence that no statistically significant differences are obtained, which implies that the scores awarded by the subjects in the study do not vary according to age, gender or education stage in which they work $(p<0.05)$. Neither are statistically significant differences observed as regards the characteristics of the sample in the pre- and post-test, which indicates sample stability.

Subsequently, an analysis was performed of the existence of statistically significant differences between the different scales into which the items in the questionnaire are divided. As can be observed in Table 4 there are no differences between them. 
Table 4: Analysis of the scales

\begin{tabular}{|c|c|c|c|c|c|c|c|c|c|}
\hline & \multirow[t]{2}{*}{$\begin{array}{l}\text { Mean } \\
\text { Pre test }\end{array}$} & \multirow[t]{2}{*}{$\begin{array}{l}\text { SD } \\
\text { Pre test }\end{array}$} & \multirow[t]{2}{*}{$\begin{array}{l}\text { Mean } \\
\text { Post test }\end{array}$} & \multirow[t]{2}{*}{$\begin{array}{c}\text { SD } \\
\text { Post test }\end{array}$} & \multicolumn{2}{|c|}{$\begin{array}{l}\text { 95\% Confidence Interval } \\
\text { of the Difference }\end{array}$} & \multirow[t]{2}{*}{$\mathrm{t}$} & \multirow[t]{2}{*}{ df } & \multirow[t]{2}{*}{ Sig. (2-tailed) } \\
\hline & & & & & Lower & Upper & & & \\
\hline Conflict & 3.008 & .434 & 3.100 & .311 & -.27638 & .06638 & -1.239 & 39 & .223 \\
\hline Process & 3.078 & .221 & 3.098 & .132 & -.10120 & .08245 & -.207 & 39 & .837 \\
\hline Community & 3.653 & .382 & 3.734 & .357 & -20197 & .10568 & -.631 & 44 & .531 \\
\hline
\end{tabular}

Note: Own elaboration.

Despite not obtaining significant differences in any of the three categories, we believed it was necessary to perform the analysis item by item, given the relevance of some of the items that represent views about conflicts, resolution, and the role of the community demonstrated by the participants in the training action.

Upon carrying out the comparison of the means between the pre-test and post-test groups, applying the T-test for independent samples, statistically significant differences were observed in 10 of the items in the questionnaire. Thereby verifying that there were changes in the beliefs and opinions of the trainees after a training period, but only in certain aspects that shall be commented in more depth in the discussion of the study.

Table 5: Comparison of means according to pre- and post- test.

\begin{tabular}{|c|c|c|c|c|c|c|}
\hline & $\begin{array}{l}\text { Mean Pre } \\
\text { Test }\end{array}$ & $\begin{array}{l}\text { SD } \\
\text { Pre Test }\end{array}$ & $\begin{array}{l}\text { Mean } \\
\text { Post Test }\end{array}$ & $\begin{array}{c}\text { SD } \\
\text { Post Test }\end{array}$ & $\mathrm{t}$ & $\begin{array}{c}\text { Sig. } \\
\text { (2-tailed) }\end{array}$ \\
\hline $\begin{array}{l}\text { Conflict represents a learning opportunity } \\
\text { and can be a drive towards change }\end{array}$ & 3.06 & .759 & 3.60 & .496 & -3.686 & .001 \\
\hline $\begin{array}{l}\text { Behaviour cannot be separated from the } \\
\text { person who does it }\end{array}$ & 2.70 & .626 & 1.38 & .750 & 1.351 & .000 \\
\hline Conflict is inherent to life in society & 3.40 & .782 & 3.43 & .807 & -.488 & .628 \\
\hline $\begin{array}{l}\text { Our attitudes and beliefs affect the way in } \\
\text { which we respond to a conflict }\end{array}$ & 3.49 & .731 & 3.60 & .538 & -1.096 & .279 \\
\hline $\begin{array}{l}\text { Most conflicts begin because of something } \\
\text { small and grow in stages. Sometimes, we } \\
\text { don't even recognise them as conflicts } \\
\text { until they begin to grow or get out of hand }\end{array}$ & 3.04 & .685 & 3.09 & .747 & -.321 & .749 \\
\hline
\end{tabular}


http://doi.org/10.15359/ree.24-2.14

ROR: https://ror.org/01t466c14 Universidad Nacional, Costa Rica

http://www.una.ac.cr/educare

educare@una.cr

\begin{tabular}{|c|c|c|c|c|c|c|}
\hline & $\begin{array}{l}\text { Mean Pre } \\
\text { Test }\end{array}$ & $\begin{array}{c}\text { SD } \\
\text { Pre Test }\end{array}$ & $\begin{array}{l}\text { Mean } \\
\text { Post Test }\end{array}$ & $\begin{array}{c}\text { SD } \\
\text { Post Test }\end{array}$ & $t$ & $\begin{array}{c}\text { Sig. } \\
\text { (2-tailed) }\end{array}$ \\
\hline $\begin{array}{l}\text { Punishment or sanction has an exemplifying } \\
\text { nature and reduces reincidence }\end{array}$ & 1.85 & .751 & 1.28 & .452 & 4.087 & .000 \\
\hline $\begin{array}{l}\text { Participation of the trainees involved is } \\
\text { essential if the conflict experienced is to be } \\
\text { adequately tackled }\end{array}$ & 3.73 & .528 & 3.77 & .428 & -.596 & .554 \\
\hline $\begin{array}{l}\text { It is important to re-establish relationships } \\
\text { between the people who have } \\
\text { experienced a conflict }\end{array}$ & 3.56 & .574 & 3.87 & .337 & -3.675 & .001 \\
\hline $\begin{array}{l}\text { The wrongdoer/offender is more likely } \\
\text { to change their behaviour if they can put } \\
\text { forward solutions to repair the harm caused }\end{array}$ & 3.31 & .643 & 3.59 & .580 & -2.000 & .052 \\
\hline $\begin{array}{l}\text { The facilitator who participates in the } \\
\text { resolution of a conflict has to encourage } \\
\text { the people involved to find a solution to } \\
\text { repair the harm caused }\end{array}$ & 3.60 & .664 & 4.00 & .000 & -4.268 & .000 \\
\hline $\begin{array}{l}\text { Punishment or sanction is what makes us } \\
\text { behave well most of the time }\end{array}$ & 1.69 & .673 & 1.21 & .414 & 4.214 & .000 \\
\hline $\begin{array}{l}\text { In a conflict it is essential that the } \\
\text { wrongdoer/offender is sanctioned/ } \\
\text { punished for the harm they have done }\end{array}$ & 1.92 & .682 & 1.38 & .491 & 4,028 & .000 \\
\hline $\begin{array}{l}\text { It is important to ask the wrongdoer/of- } \\
\text { fender, why did you do that? }\end{array}$ & 2.73 & 1.021 & 2.50 & 1.243 & 1.098 & .278 \\
\hline $\begin{array}{l}\text { It is often the person who is judged, not } \\
\text { the deed }\end{array}$ & 2.75 & .796 & 3.40 & .538 & -4.272 & .000 \\
\hline $\begin{array}{l}\text { Everybody has a right to be listened to } \\
\text { with respect, even the wrongdoer/offender }\end{array}$ & 3.98 & .139 & 3.91 & .282 & 1.353 & .183 \\
\hline $\begin{array}{l}\text { It is important for the wrongdoer/offender to } \\
\text { think of the impact of their actions on others } \\
\text { and of how to repair the harm caused }\end{array}$ & 3.79 & .498 & 3.91 & .282 & -1.430 & .160 \\
\hline $\begin{array}{l}\text { The application of a punishment or sanction } \\
\text { is the final element in tackling a conflict }\end{array}$ & 1.86 & .926 & 1.30 & .462 & 3.234 & .002 \\
\hline $\begin{array}{l}\text { To tackle a conflict it is very important for } \\
\text { the offended/affected person to be able to } \\
\text { express how they felt and what they need } \\
\text { to feel better }\end{array}$ & 3.86 & .348 & 3.94 & .247 & -1.000 & .323 \\
\hline
\end{tabular}


http://doi.org/10.15359/ree.24-2.14 ROR: https://ror.org/01t466c14 Universidad Nacional, Costa Rica

\begin{tabular}{|c|c|c|c|c|c|c|}
\hline & $\begin{array}{l}\text { Mean Pre } \\
\text { Test }\end{array}$ & $\begin{array}{l}\text { SD } \\
\text { Pre Test }\end{array}$ & $\begin{array}{l}\text { Mean } \\
\text { Post Test }\end{array}$ & $\begin{array}{c}\text { SD } \\
\text { Post Test }\end{array}$ & $t$ & $\begin{array}{c}\text { Sig. } \\
\text { (2-tailed) }\end{array}$ \\
\hline $\begin{array}{l}\text { It is very important for the people involved } \\
\text { to reach solutions collaboratively }\end{array}$ & 3.75 & .480 & 3.96 & .204 & -2.444 & .018 \\
\hline $\begin{array}{l}\text { It is more important to heal hurts than to } \\
\text { penalise }\end{array}$ & 3.65 & .653 & 4.00 & .000 & -3.675 & .001 \\
\hline $\begin{array}{l}\text { Conflict can be considered resolved when } \\
\text { the two parties are satisfied }\end{array}$ & 3.39 & .666 & 3.66 & .562 & -1.904 & .063 \\
\hline $\begin{array}{l}\text { Group cohesion is fundamental to prevent- } \\
\text { ing conflicts }\end{array}$ & 3.76 & .428 & 3.83 & .433 & -.467 & .642 \\
\hline $\begin{array}{l}\text { Improving coexistence means paying } \\
\text { attention to the normal way we communi- } \\
\text { cate with each other }\end{array}$ & 3.63 & .564 & 3.89 & .312 & -2.482 & .017 \\
\hline $\begin{array}{l}\text { The better people know each other the } \\
\text { more likely they are to resolve conflicts }\end{array}$ & 3.33 & .785 & 3.30 & 1.020 & .334 & .740 \\
\hline $\begin{array}{l}\text { One of the things that help improve coex- } \\
\text { istence and decrease conflicts is for people } \\
\text { to appreciate each other }\end{array}$ & 3.54 & 699 & 3.55 & .717 & .000 & 1.000 \\
\hline $\begin{array}{l}\text { Being reintegrated into a group, re-estab- } \\
\text { lishing relationships, is as important as } \\
\text { repairing harm }\end{array}$ & 3.77 & .425 & 3.83 & .433 & -.467 & .642 \\
\hline $\begin{array}{l}\text { In order to resolve a conflict it is important } \\
\text { that the wrongdoer/offender feels that they } \\
\text { are part of the community and they realise } \\
\text { the consequencies of their actions in it }\end{array}$ & 3.75 & .480 & 4.00 & .000 & -3.370 & .002 \\
\hline
\end{tabular}

Note: Own elaboration.

As regards the results obtained from the discussion group concerning the effectiveness of the training strategies in restorative practices, below we show the results based on the categories emerging from the qualitative analysis:

\section{Effective training strategies}

\section{Start from the experiences of the attendees}

The starting point was the personal and professional experiences of the attendees, as this makes it easier to be more aware and verbally explicit as to how their behaviour affects the people they live alongside (family, work...). 
http://doi.org/10.15359/ree.24-2.14

ROR: https://ror.org/01t466c14 Universidad Nacional, Costa Rica

http://www.una.ac.cr/educare

educare@una.cr

Moreover, throughout the training, opportunities arose to express personal needs, according to personal experiences, as can be seen in the following activity proposed during the training:"Briefly write abourt a conflict you have recently had at work, in which you have hurt or you have been hurt. What would you have needed in that situation?"

The situations of conflict put forward in the practical activities are close to the participants, to their everyday reality. Their involvement is sought in the conflict analysis, in the search for solutions, and in restoring the relationships affected. In these situations of conflict, the attendees adopt different roles: facilitator, offender, offended, person of support, member of the community, observer...

\section{Active, constant participation of the attendees}

Trainee participation is present throughout the training sessions. In the more informal training activities on restorative practices, attendees practise active listening, expressions of affect; and also experience their absence, in such a way that the positive effect of these practices are more evident.

The fact described in the above category has a positive affect on participation, in relation to personal and professional experience. Thus, for instance, when authority styles are addressed (Social Discipline Window), the involvement of the attendees is easy, both when they have to put themselves in the shoes of another person, and when they analyse their own customary behaviour before people over whom they have some sort of authority (pupils, their own children...).

Dialogue is fully present throughout the training sessions. All the attendees can express themselves and, above all, feel they are being listened to; both conditions are essential for their participation.

\section{Modelling}

The trainers act as a model of restorative intervention on the basis of the key principles and values of restorative practices: respect, recognition, positive attitude, empathy, positive view of conflicts; they create connection, place importance on the feelings and needs of particpants, listen actively, promote the feeling of community...

\section{Implementation of the different restorative strategies most related to their professional activity}

The repertoire that is practised covers from the most informal to restorative circles. Thereby, the aim is for attendees to get to know restorative strategies and the values underpinning them from their use. 
The elements that define a community are explained, from the experiences of the attendees: cooperation, knowledge of others, respect and concern for their wellbeing.... At the same time, activities are proposed in which they interact, do things together, discuss what matters to them, establish affective ties and make decisions as a group and as individuals regarding restorative practices.

Over half of the training time is engaged in creating community between attendees and in giving examples of situations from their workplace in which they could apply preventive restorative practices.

Throughout the explanations and reflection on the practical situations, reference is made to fair process as a basic element to relate with each other restoratively. References to this process (clear goals, transparency, and participation) help to better understand each of the restorative practices.

Restorative practices connect with the desire to feel good within the community and to make others feel good. The simplicity of some of the proposals helps people realise that all it often takes is to pay attention to others.

\section{Relationship with the professional commitment of the attendees}

For the purpose of emphasising the application of restorative practices and their not remaining as a training activity, throughout the sessions the following questions are stressed: What can I do in my work? What can I apply and for what purpose? What do I need in order to do it?

Attendees are empowered to draw up an implementation plan suitable to their place of work, and they are given the chance to think about what type of school they desire and how they want to relate to their pupils and their colleagues on the basis of reflective questions such as: "Do you think it will be beneficial for your work? What use is the window to us?"

\section{Discussion}

The results show that there are significant changes in some of the items assessed in the questionnaire. We decided to analyse each of these changes and to find out the causes of the existing variations.

On the one hand, we identified the items that refer to basic principles of Restorative Practices and, as such, were addressed in the training in such a way that they brought about a change in the perceptions of the trainees: 
http://doi.org/10.15359/ree.24-2.14

ROR: https://ror.org/01t466c14 Universidad Nacional, Costa Rica

http://www.una.ac.cr/educare

educare@una.cr

Conflict represents a learning opportunity and can be a driving force for change:

It is important to re-establish relationshps between the people who have been involved in a conflict (trainer 5).

In a conflict it is essential for the wrongdoer/offender to be sanctioned/punished for the harm they have done (trainer 6).

It is often the person who is judged, not the deed (trainer 2).

It is more important to heal hurts than to penalise (trainer 1).

Behaviour cannot be separated from the person who does it (trainer 2).

These items make up the basis of Restorative Practices. The purpose of re-establishing relationships and incorporating the person who caused harm into the community is only possible if the positive side of the conflict is contemplated and the deed is separated from the person (Costello et ál., 2009).

Secondly, there is a series of items that refer to the limitations of the punishment or sanction, to its low impact on behaviour change by not contributing to the person taking responsibility for the harm caused to another person or persons:

Punishment or sanction has an exemplifying nature and reduces reincidence (trainer 4).

Punishment or sanction is what makes us behave well most of the time (trainer 2)

Application of a punishment or sanction is the final element in tackling a conflict (trainer 3).

These references are arguments that from Restorative Practices are used to promote a change in tackling conflicts and failure to comply with established standards (Zehr, 2005).

Finally, there are some statements that refer to the intervention strategies that characterise Restorative Practices that were explicitly developed during the training:

The facilitator who participates in the resolution of a conflict has to encourage the people involved to find a solution to repair the harm caused (trainer 5).

In order to resolve a conflict it is important that the wrongdoer/offender feels that they are part of the community and they realise the consequences of their actions in it (trainer 6). 
As regards the indicators of the questionnaire that did not undergo changes with respect to the pre-test after receiving the training action that we analyse in this article, various causes can be establishe

- As this training was voluntary, this implies there were a high percentage of attendees who were already motivated and sensitive to the issue. Choosing this issue could reveal a prior interest in conflict resolution and being aware that there are alternatives to the traditional resolution thereof. These results demonstrate a willingness to change and improve their approach to conflicts in the classroom; making restorative practices an alternative to already known responses that did not have the desired results.

- Conflict and its resolution is an issue that has been greatly developed in the world of education; although restorative practices correspond to a new philosophy in their approach, the education community has received general training in conflict resolution; this prior knowledge justifies the lack of changes in generalised statements in the questionnaire such as:

Conflict is inherent to life in society;

It is important that the wrongdoer/offender thinks about the impact of their actions on others and how to repair the harm caused (trainer 4).

In order to address a conflict it is very important that the offended/affected person can express how they felt and what they need to feel better (trainer 6).

There are statements that correspond to the effect of social desirability, a concept developed by Crowne \& Marlowe (1964):

The wrongdoer/offender is more likely to change their behaviour if they can put forward solutions to repair the harm caused (trainer 4).

Participation of the students involved is most necessary if you want to properly deal with the conflict experienced (trainer 1).

It is very important that the persons involved reach solutions collaboratively (trainer 2).

Conflict can be considered resolved when the two parties are satisfied (trainer 1).

Group cohesion is fundamental to preventing conflicts (trainer 3). 
http://doi.org/10.15359/ree.24-2.14

ROR: https://ror.org/01t466c14 Universidad Nacional, Costa Rica

http://www.una.ac.cr/educare

educare@una.cr

Improving coexistence involves paying attention to the normal way we communicate. One of the things that helps improve coexistence and decrease conflicts is for people to appreciate one another (trainer 5).

Being reintegrated in a group, re-establishing relationships, is as important as repairing the harm (trainer 4).

What is politically correct in these cases is to award high scores to these statements due to the existing social awareness of the issue.

- The Questionnaire on beliefs and opinions regarding restorative practices has a series of limitations; including the inadequate expression of the items listed below, as they were too evident in an issue that was already present in the education community, namely conflicts and their resolution:

Our attitudes and beliefs affect the way in which we respond to a conflict.

Most conflicts begin as something small and grow in stages. Sometimes, we don't even recognise them as conflicts until they begin to grow or get out of hand

Everybody has the right to talk and be listened to with respect, even the wrongdoer/offender.

The better people know each other, the more likely they are to resolve conflicts

Finally, there is one item that reveals no change due to the training: It is important to ask the wrongdoer/offender, why did you do that? The explanation could be dual: on the one hand, that the ineffectiveness of this question was not sufficiently stressed during the training (according to the proposal of restorative practices); and on the other hand, because it is a deeply rooted question in the habitual approach to conflicts or when faced with inappropriate behaviour.

As regards training strategies, these are valued positively by the components of the discussion group, highlighting the constant invitation to participate, the fact of relating the personal and professional experiences of the attendees with the different restorative practices addressed, and the insistence on their subsequent application in their workplaces.

Nevertheless, we cannot forget that although the teaching strategies were flagged as very functional, there is a series of factors that hinder a profound change in the attitudes and knowledge of the attendees towards training actions. One of these is the length of the training; its brevity conditions the training goal to mere sensitisation to the issue. On the other hand, the fact that the training was voluntary and did not take place with all the members of a teaching faculty (for instance), simplifies its implementation in classrooms in the hands of certain tutors 
and not as a school project. Lastly, the lack of a demand on behalf of the education authority for teaching commitments based on a training action also conditions the onset and continuity of processes of change in education establishments.

With respect to the limitations of the study, the following are pointed out:

1) It is necessary to expand and diversify the sample, as well as to assess the stability of the change through successive post-tests. The methodological design of this study has limitations in terms of its implementation, as there was no control group.

2) The limitations of the study revolve around the generalisation and validity of the results, with two standing out. On the one hand, a study design with a single experimental group and with no control group, such that the results must be interpreted with caution. The other limitation is the relatively small sample. Nevertheless, this was a pilot study and the aim was to address the field of study in order to subsequently analyse the real impact of the training in education establishments.

3) It refers only to the initial training in restorative practices and does not analyse their subsequent application. The study is the starting point of a broader project on the implemention of training in restorative practices in education establishments in the Balearic Islands and its impact in the life of students and staff. The growing body of research regarding the effectiveness of restorative practices (Gray \& Drewery, 2011; MCluskey et ál, 2008; Reimer, 2011; Vaandering, 2013), among others; is evidence of their progressive implementation and of the need to analyse their implementation.

Regarding the strong points of the study, the following stand out:

1) We believe this study can contribute to the background knowledge of trainers in restorative practices as it reveals two key questions: on the one hand, training in restorative practices modifies views on conflict and how to tackle it; on the other hand, it reinforces the effectiveness of teacher training that, based on the prior experiences of the participants, encourages their participation, focuses on practice, and emphasises the implementation of changes in the workplaces.

2) With this study we have begun a new line of research that combines the assessment of the impact and transferal of training of teaching staff with a new proposal to improve coexistence in education establishments, namely restorative practices.

\section{Conclusions}

In the search for school cultures that are more participative, welcoming and caring in terms of relationships (a peaceful school culture), restorative practices are becoming one of the ways to achieve this. Little by little, more and more schools in different countries are choosing to 
http://doi.org/10.15359/ree.24-2.14

ROR: https://ror.org/01t466c14 Universidad Nacional, Costa Rica

http://www.una.ac.cr/educare

educare@una.cr

introduce RP in order to improve community life and to tackle conflict resolution in a different way. In our country over the last five years, restorative justice has progressively been incorporated into educational instiutions. This new scenario requires making teacher training essential.

The present study contributes to the analysis of the impact of training in restorative practices on the values and attitudes of teachers towards conflicts, considering both the contents of the proposal and the training strategies used. This research suggests that training in restorative practices has an impact on attitude change, which is essential for the commitment of teaching staff to implementing restorative practices. We are aware that this is not enough to make school centres safer and more caring environments. A firm commitment is needed from the education administration in order to facilitate the adoption of new responses.

From the study carried out it can be concluded that restorative practices offer teaching staff a theoretical and practical framework on the basis of which they will be able to:

1. Promote personal relationships between pupils based on a community perspective.

2. Acquire strategies to enable shared resolution of conflicts.

3. Develop strategies to promote situations of exchange and participation.

4. Take care of relationships between the people making up the educational community.

At the same time it can be concluded that training in restorative practices enables a more comprehensive improvement of teaching staff by making knowing how to be a fundamental axis of the training process. Having experienced joint reflection, shared work, and mutual support throughout the training sessions, based on values of respect and real participation, empowers the participants to be better equipped to cope with the many challenges they face in school centres with greater willingness and strength.

It is precisely restorative practices that offer some essential keys to implementing educational changes. In other words, training in restorative practices, even if only briefly, makes it clear that change and improvement require:

- Real participation and engagement of the people involved.

- A sense of collaborative work and mutual support.

- Autonomy and initiative of people in decision-making concerning the changes desired and processes of improvement.

- A greater willingness to solve problems and difficulties through dialogue.

- Open communication where everyone feels listened to, acknowledged and appreciated. 


\section{References}

Abraham, R., Ramnarayan, K., \& Kamath, A. (2008). Validating the effectiveness of Clinically Oriented Physiology Teaching (COPT) in undergraduate physiology curriculum. BMC Medical Education, 8(40), 1-5. https://doi.org/10.1186/1472-6920-8-40

Associació de Justícia i Pràctica Restaurativa. (2016). Associació de Justícia i Pràctica Restaurativa de les Illes Balears. https://sites.google.com/a/practicarestaurativa.org/associacio-dejusticia-i-practica-restaurativa/el-centre

Braithwaite, J. (2002). Restorative justice and responsive regulation. Oxford University Press.

Braithwaite, J. (2006). Doing justice intelligently in civil society. Journal of Social Issues, 62(2), 393-409. https://doi.org/10.1111/j.1540-4560.2006.00456.x

Britto, D. (2006). Justicia restaurativa, otra forma de establecer disciplina. Justicia Restaurativa en Línea.

Cortina, J. M. (1993). What is coefficient alpha? An examination of theory and applications. Journal Applied Psycholofy, 78(1), 98-104. https://doi.org/10.1037/0021-9010.78.1.98

Costello, B., Wachtel, J., \& Wachtel, T. (2009). The restorative practices handbook for teachers, disciplinarians and administrators. International Institute for Restorative Practices.

Costello, B., Wachtel, T., \& Wachtel, J. (2010). Restorative circles in schools: Building community and enhancing learnig. International Institute for Restorative Practices.

Crowne, D. P., \& Marlowe, D. (1964). The approval motive: Studies in evaluative dependence. Wiley.

Degani, A.T., Patel, R. M., Smith, B. E., \& Grimsley, E. (2009). The effect of student training on accuracy of completion of death certificates. Medical Education Online, 14(1), 1-5. https:// doi.org/10.3402/meo.v14i.4510

Entwistle, N. (1998). Conceptions of learning. Understanding and teaching in higher education. Scre Fellowship Lecture.

Feuillette-Cunningham, I. (1995). Le nouveau formateur. Comment preparer, animer et évaluer une action de formation. Dunod.

Gray, S., \& Drewery, W. (2011). Restorative practices meet key competencies: Class meetings as pedagogy. International Journal on School Disaffection, 8(1) 13-21. https://doi. org/10.18546/IJSD.08.1.03

Hall, M., Ramsay, A., \& Raven, J. (2004). Changing the learning environment to promote deep learning approaches in first-year accounting students. Journal Accounting Education, 13(4), 489-505. https://doi.org/10.1080/0963928042000306837

Hopkins, B. (2004). Just schools: A whole school approach to restorative justice. Jessica Kingsley.

Hopkins, B. (2011). The restorative classroom. Using restorative approaches to foster effective 
http://doi.org/10.15359/ree.24-2.14

ROR: https://ror.org/01t466c14 Universidad Nacional, Costa Rica

http://www.una.ac.cr/educare

educare@una.cr

learning. Optimus Education.

International Institute for Restorative Practices. (2019). Restoring Community. https://www.iirp.edu/

Johnstone, J.W. C., \& Rivera, R. J. (1965). Volunteers for learning. A study of the educational pursuits of American adults. Aldine.

Jurado, P. (1996). Requisits de l'aprentatge. UOC.

McCluskey, G, Lloyd, G., Kane, J., Riddell, S., Stead, J., \& Weedon, E. (2008). Can restorative practices in schools make a difference? Educational Review, 60(4), 405-417. https://doi. org/10.1080/00131910802393456

McCold, P., \&Wachtel,T. (2003). In pursuit of paradigm:A theory of restorativejustice. Restorative Practices EForum. https://www.iirp.edu/news/in-pursuit-of-paradigm-a-theory-of-restorative-justice

Mirsky, L. (2011). Restorative practices: Giving everyone a voice to create safer Saner School Communities. The Prevention Researcher, 18(5), 3-6. https://doi.org/10.1037/e542592012-002

Morrison, B. (2006). School bullying and restorative justice: Toward a theoretical understanding of the role of respect, pride, and shame. Journal of Social Issues, 62(2), 371-392. https://doi. org/10.1111/j.1540-4560.2006.00455.x

Morrison, B., Blood, P., \& Thorsborne, M. (2005). Practising restorive justice in school communities: Addresdsing the challenge of culture change. Public Organisation Review, 5(4), 335-357. https://doi.org/10.1007/s11115-005-5095-6

Reimer, K. (2011). An exploration of the implementation of restorative justice in an Ontario public school. Canadian Journal of Educational Administration and Policy, 119, 1-42. https:// eric.ed.gov/?id=EJ923619

Schmitt, N. (1996). Uses and abuses of coefficient alpha. Psychological Assessment, 8(4), 350-353. https://doi.org/10.1037/1040-3590.8.4.350

Streiner, D. L. (2003). Starting at the beginning: An introduction to coefficient alpha and internal consistency. Journal of Personality Assessment, 80(1), 99-103. https://doi.org/10.1207/ S15327752JPA8001 18

Vaandering, D. D. (2013). Student, teacher, and administrator perspectives on harm: Implications for implementing safe and caring school initiatives. Review of Education, Pedagogy, and Cultural Studies, 35(4), 298-318. https://doi.org/10.1080/10714413.2013.825514

Vaandering, D.D. (2014). Implementing restorative justice practice in schools:What pedagogy reveals, Journal of Peace Education, 11(1), 64-80, https://doi.org/10.1080/17400201.2013.794335

Woolfolk, A. E., \& MacCuna, L. (1980). Educational psychology for teachers. Prentice-Hall.

Zehr, H. (2005). Changing lenses: A new focus for crime and justice (3rd ed.). Herald Press.

María lsabel Pomary Carme Pinya

Los artículos de la Revista Electrónica Educare del Centro de Investigación y Docencia en Educación de la Universidad Nacional, Costa Rica, se comparten bajo términos de la Licencia Creative Commons: Reconocimiento, No Comercial, Sin Obra Derivada 3.0 Costa Rica. Las autorizaciones adicionales a las aquí delimitadas se pueden obtener en el correo: educare@una.cr 